\title{
Effect of Surgery on Tumour-directed Leucocyte Responses
}

\author{
B. M. VOSE, G. C. MOUDGIL
}

British Medical fournal, 1975, 1, 56-58

\begin{abstract}
Summary
Leucocytes from 22 out of 26 patients with mammary carcinoma were significantly cytotoxic in vitro for cells cultured from mammary tumours though only two out of 17 of these preparations were cytotoxic for cells cultured from tumours arising at other sites. In the immediate postoperative period reactivity of patients' leucocytes with mammary tumour cells was undetectable but returned within one week of surgery. Leucocyte cytotoxicity may therefore offer a model in which the mechanism of postoperative depression of immunological competence may be investigated.
\end{abstract}

\section{Introduction}

Cell-mediated responses to human breast malignancy have been extensively investigated by the cytotoxicity in vitro of allogeneic peripheral blood leucocytes for cells cultured from tumour specimens (Hellström et al., 1971; Fossati et al., 1972; Baldwin et al., 1973). The consensus of opinion is that such leucocytes show a relatively specific reactivity for cells derived from mammary tumours so that cytotoxicity against cells cultured from tumours arising at other anatomical sites is rare.

Several authors have reported a general depression of immunological competence after surgical procedures performed under general anaesthesia (Riddle and Berenbaum, 1967; Park et al., 1971). Our objective was to assess the effect of surgery under general anaesthesia on human tumour-directed immunological responses in the immediate postoperative period as shown by the cytotoxicity of leucocyte preparations from patients with breast tumours for cells cultured from breast tumours.

\section{Patients and Methods}

\section{INITIATION OF TISSUE CULTURES}

Tumours were obtained from seven patients undergoing simple mastectomy for confirmed mammary carcinoma and taken to the laboratory within two hours of their removal for the initiation of tissue cultures. As much stroma and fatty material as possible was removed from the specimen before it was finely chopped with scissors and washed in Hank's balanced salt solution (H.B.S.S.). Tissue fragments $\left(1-2 \mathrm{~mm}^{3}\right)$ were allowed to adhere to the surface of $25-\mathrm{cm}^{2}$ Falcon flasks or alternatively dissociated into single cell suspensions with $0.25 \%$ trypsin in the presence of DNAse. Cells were harvested by centrifugation $(30 \mathrm{~g})$, washed in H.B.S.S., and $5 \times 10^{5}-5 \times 10^{6}$ cells were seeded into flasks. Cultures were maintained by serial subculture in Waymouth's medium supplemented with $20 \%$ fetal

Department of Immunology, Paterson Laboratories, Christie Hospital and Holt Radium Institute, Manchester M20 9BX

B. M. VOSE, B.PHARM., PH.D., Scientific Officer

Department of Anaesthetics, Withington Hospital, Manchester M20 8LR

G. C. MOUDGIL, M.B., F.F.A. R.C.S., Senior Registrar calf serum and antibiotics and used as targets for leucocytotoxicity tests between the first and tenth passage. Control cell cultures from colon, lung, or bladder carcinomas were initiated and maintained in an identical manner.

\section{PATIENTS}

Patients were premedicated with intramuscular pethidine $50 \mathrm{mg}$ and promethazine hydrochloride $50 \mathrm{mg}$ given one hour before surgery. All patients underwent simple mastectomy and were induced with intravenous thiopentone $5 \mathrm{mg} / \mathrm{kg}$ and intubated after intravenous suxamethonium $1 \mathrm{mg} / \mathrm{kg}$. Anaesthesia was maintained with oxygen $31 / \mathrm{m}$, nitrous oxide $6 \mathrm{l} / \mathrm{m}$, and halothane $1-2 \%$ delivered by a Fluote Mark III vaporizer through a Magill circuit. The duration of anaesthesia was 45-60 minutes. All patients had $500 \mathrm{ml}$ of normal saline intravenously and none needed blood transfusion. Throughout the procedure patients were monitored electrocardiographically and for blood pressure and respiration, and no abnormality was detected.

\section{LEUCOCYTES}

Heparinized blood samples $(10 \mathrm{ml})$ were taken from 26 patients one day before operation and in a few cases after induction but before surgery, at varying times after surgery, and one week after surgery. Two additional patients had blood samples taken after the operation for immediate postoperative testing alone. Age- and sex-matched healthy control specimens were obtained from the National Blood Transfusion Service.

Leucocytes were prepared by centrifugation of blood samples on gradients of Ficoll (Pharmacia, Uppsala) and Triosil (Nyegaard and Co., Oslo) by the method of Böyum (1968). This resulted in a preparation containing a mean $( \pm$ S.E.) of $70 \pm 6 \%$ lymphocytes with a minimal erythrocyte contamination but variable granulocyte and thrombocyte contamination and $1-2 \%$ monocytes. Leucocytes were washed three times in H.B.S.S. before resuspension for counting in Eagle's M.E.M. buffered with $40 \mathrm{mM}$ HEPES (N-2-hydroxyethylpiperazine$\mathrm{N}^{1}$-ethanesulphonic acid) supplemented with $10 \%$ fetal calf serum.

\section{MICROCYTOTOXICITY TESTS}

The cytotoxicity of peripheral blood leucocytes for cultured target cells was determined by the microassay method of Takasugi and Klein (1970) or the modification described by Hellström et al. (1971). Briefly, 100-200 target cells were seeded into the wells of Microtest I plates No. 3034 or Microtest II plates No. 3040 (Falcon Plastics Co., Los Angeles) in Eagle's M.E.M. buffered with HEPES and supplemented with $10 \%$ fetal calf serum. After four to 24 hours incubation at $37^{\circ} \mathrm{C}$ to allow cell attachment the medium was replaced by leucocyte suspension $\left(2 \times 10^{5}\right.$ cells/well in Microtest II and sufficient to give an effector:target cell ratio of 75:1 in Microtest I plates). After a further two days incubation the non-adherent cells were removed by washing with saline and remaining cells were fixed with methanol and stained with crystal violet. The number of cells surviving in each of 10 wells was counted and the percen- 
tage cytotoxicity or cytotoxic index of leucocyte preparations calculated as follows:

mean no. survivors mean no. survivors in wells treated with in wells treated control leucocytes - with patients leucocytes

cytotoxic index $=\overline{\text { mean no. survivors in wells treated with }}$ control leucocytes

The significant level of the cytotoxic index was determined by Student's $t$ test. P values of less than 0.05 were taken to represent a significant event. All tests on given patients were performed on one of the seven tumour-cell cultures initiated. The control leucocytes were prepared on the same day as the patients' leucocytes and tested against the same tumour cell line.

\section{Results}

Leucocytes taken from patients with confirmed mammary carcinoma before the operation were generally cytotoxic for cells cultured from mammary tumours compared with the effect of those from age- and sex-matched controls (table I). Of 26

TABLE I-Cytotoxicity of Peripheral Blood Leucocytes taken Preoperatively from Patients with Mammary Carcinoma for Cultured Cells from Mammary Carcinomas

\begin{tabular}{|c|c|c|c|c|}
\hline \multirow[t]{2}{*}{ Case No. } & \multicolumn{2}{|c|}{$\begin{array}{l}\text { Mean No. }( \pm \text { S.E. }) \text { of Cells } \\
\text { surviving Treatment with } \\
\text { Leucocytes from: }\end{array}$} & \multirow{2}{*}{$\begin{array}{c}\text { Cytotoxic } \\
\text { Index }\end{array}$} & \multirow[t]{2}{*}{$\mathbf{P}<$} \\
\hline & Control & Patient & & \\
\hline $\begin{array}{r}1 \\
2 \\
3 \\
4 \\
5 \\
6 \\
7 \\
8 \\
9 \\
10 \\
11 \\
12 \\
13 \\
14 \\
15 \\
16 \\
17 \\
18 \\
19 \\
20 \\
21 \\
22 \\
23 \\
24 \\
25 \\
26\end{array}$ & $\begin{array}{r}104 \pm 3 \\
134 \pm 8 \\
52 \pm 3 \\
40 \pm 1 \\
83 \pm 10 \\
50 \pm 7 \\
50 \pm 7 \\
238 \pm 14 \\
55 \pm 7 \\
55 \pm 7 \\
74 \pm 4 \\
74 \pm 4 \\
74 \pm 4 \\
24 \pm 2 \\
24 \pm 2 \\
67 \pm 5 \\
67 \pm 5 \\
21 \pm 2 \\
118 \pm 4 \\
89 \pm 6 \\
84 \pm 3 \\
78 \pm 1 \\
214 \pm 14 \\
37 \pm 5 \\
37 \pm 5 \\
72 \pm 6\end{array}$ & $\begin{array}{r}78 \pm 9 \\
84 \pm 4 \\
24 \pm 3 \\
31 \pm 1 \\
41 \pm 5 \\
30 \pm 2 \\
22 \pm 2 \\
140 \pm 11 \\
52 \pm 7 \\
18 \pm 5 \\
57 \pm 3 \\
55 \pm 3 \\
57 \pm 4 \\
18 \pm 1 \\
22 \pm 1 \\
70 \pm 4 \\
97 \pm 8 \\
11 \pm 1 \\
31 \pm 4 \\
17 \pm 4 \\
57 \pm 2 \\
41 \pm 4 \\
122 \pm 11 \\
28 \pm 2 \\
24 \pm 4 \\
30 \pm 3\end{array}$ & $\begin{array}{r}25 \\
37 \\
54 \\
23 \\
51 \\
40 \\
56 \\
41 \\
5 \\
61 \\
24 \\
26 \\
23 \\
23 \\
9 \\
-4 \\
-44 \\
46 \\
74 \\
81 \\
32 \\
48 \\
43 \\
26 \\
35 \\
43\end{array}$ & $\begin{array}{l}0.01 \\
0.0005 \\
0.0005 \\
0.0025 \\
0.0005 \\
0.005 \\
0.0005 \\
0.0005 \\
0.40 \\
0.0005 \\
0.0005 \\
0.0005 \\
0.0025 \\
0.005 \\
0.15 \\
\\
\\
0.0005 \\
0.0005 \\
0.0005 \\
0.0005 \\
0.0005 \\
0.0005 \\
0.05 \\
0.025 \\
0.0005\end{array}$ \\
\hline
\end{tabular}

leucocyte preparations tested 22 had significant cytotoxic indices. Different patients' leucocyte preparations showed marked variation in cytotoxic index ( -44 to 81 ) but this could not be correlated with the apparent disease stage. Two of the patients (cases 1 and 5) had advanced breast malignancy and were judged to be inoperable. Leucocyte preparations from these patients, however, produced significant reductions of cell survival of mammary tumour cultures compared with those from controls. In two tests (cases 8 and 23) against two different target cells both control and patients' leucocyte preparations stimulated target cell growth. These leucocytes were unfortunately not available for subsequent studies and there was no obvious explanation for this effect. All tests were performed in allogeneic combination using 19 separate control preparations. No attempt was made to select controls with low reactivity against cells derived from mammary cultures.

Of the leucocyte suspensions taken preoperatively from 26 patients-those of 17 were tested against cells cultured from tumours arising at anatomical sites other than the breast.
Significant cytotoxic indices were rare and detected in only two cases (table II) against cells from lung carcinoma (case 21) and colon carcinoma (case 22) cultures.

TABLE II-Cytotoxicity of Peripheral Blood Leucocytes taken Preoperatively from Patients with Mammary Carcinoma for Cultured Cells from Tumours arising at Sites other than Breast

\begin{tabular}{|c|c|c|c|c|c|}
\hline \multirow[t]{2}{*}{ Case No. } & \multirow[t]{2}{*}{ Target Cells } & \multicolumn{2}{|c|}{$\begin{array}{l}\text { Mean No. ( } \pm \text { S.E. }) \text { of } \\
\text { Cells surviving Treat- } \\
\text { ment with Leucocytes } \\
\text { from: }\end{array}$} & \multirow{2}{*}{$\begin{array}{c}\text { Cytotoxic } \\
\text { Index }\end{array}$} & \multirow[t]{2}{*}{$\mathbf{P}<$} \\
\hline & & Control & Patient & & \\
\hline 1 & Colon & $49 \pm 2$ & $40 \pm 4$ & 18 & $0 \cdot 10$ \\
\hline 2 & $\begin{array}{l}\text { carcinoma } \\
\text { Colon }\end{array}$ & $211 \pm 9$ & $174 \pm 23$ & 18 & $0 \cdot 10$ \\
\hline 3 & $\begin{array}{l}\text { carcinoma } \\
\text { Basal cell }\end{array}$ & $118 \pm 6$ & $135 \pm 8$ & -15 & \\
\hline 4 & Basal cell & $118 \pm 6$ & $124 \pm 7$ & -5 & \\
\hline 5 & $\begin{array}{l}\text { carcinoma } \\
\text { Bladder }\end{array}$ & $85 \pm 5$ & $86 \pm 10$ & -1 & \\
\hline 9 & $\begin{array}{l}\text { cancer } \\
\text { Colon }\end{array}$ & $144 \pm 20$ & $172 \pm 19$ & -19 & \\
\hline 10 & $\begin{array}{l}\text { carcinoma } \\
\text { Colon }\end{array}$ & $144 \pm 20$ & $142 \pm 18$ & 1 & 0.475 \\
\hline 11 & $\begin{array}{l}\text { carcinoma } \\
\text { Colon }\end{array}$ & $59 \pm 3$ & $61 \pm 4$ & -5 & \\
\hline 12 & $\begin{array}{l}\text { carcinoma } \\
\text { Colon }\end{array}$ & $59 \pm 3$ & $62 \pm 3$ & -5 & \\
\hline 13 & $\begin{array}{l}\text { carcinoma } \\
\text { Colon }\end{array}$ & $59 \pm 3$ & $63 \pm 3$ & -7 & \\
\hline 14 & $\begin{array}{l}\text { carcinoma } \\
\text { Lung }\end{array}$ & $38 \pm 5$ & $38 \pm 4$ & 0 & \\
\hline 15 & $\begin{array}{l}\text { carcinoma } \\
\text { Lung }\end{array}$ & $38 \pm 5$ & $40 \pm 3$ & 5 & \\
\hline 18 & $\begin{array}{l}\text { carcinoma } \\
\text { Colon }\end{array}$ & $65 \pm 4$ & $62 \pm 4$ & 6 & $0 \cdot 25$ \\
\hline 19 & $\begin{array}{l}\text { carcinoma } \\
\text { Colon }\end{array}$ & $65 \pm 4$ & $59 \pm 4$ & 10 & 0.15 \\
\hline 20 & $\begin{array}{l}\text { carcinoma } \\
\text { Colon }\end{array}$ & $101 \pm 11$ & $95 \pm 6$ & 6 & 0.30 \\
\hline 21 & $\begin{array}{l}\text { carcinoma } \\
\text { Lung }\end{array}$ & $144 \pm 7$ & $54 \pm 2$ & 62 & 0.0005 \\
\hline 22 & $\begin{array}{c}\text { carcinoma } \\
\text { Colon } \\
\text { carcinoma }\end{array}$ & $211 \pm 9$ & $162 \pm 12$ & 23 & 0.0025 \\
\hline
\end{tabular}

Peripheral blood leucocytes from 17 patients were tested postoperatively for cytotoxicity against cells derived from mammary tumours. Fourteen patients had significant cytotoxic indices when tested preoperatively (tables I and III). Leucocytes from 15 out of 17 patients failed to evoke a significant

TABLE III-Variation of Cytotoxic Index of Leucocytes from Mammary Tumour Patients for Cells cultured from Mammary Carcinomas immediately after Operation

\begin{tabular}{|c|c|c|c|}
\hline \multirow{2}{*}{ Case No. } & \multicolumn{3}{|c|}{ Cytotoxic Index } \\
\hline & Before Operation & $\begin{array}{c}0-1 \text { Day } \\
\text { After Operation }\end{array}$ & $\begin{array}{c}\text { 7-8 Days } \\
\text { After Operation }\end{array}$ \\
\hline $\begin{array}{r}2 \\
6 \\
10 \\
11 \\
12 \\
13 \\
14 \\
17 \\
18 \\
19 \\
20 \\
21 \\
22 \\
24 \\
26 \\
27 \\
28\end{array}$ & $\begin{array}{c}37^{* * *} \\
40^{* * *} \\
61^{* * *} \\
24 * * * \\
26^{* * *} \\
23^{* * *} \\
23 * * \\
-44 \\
46^{* * *} \\
74^{* * *} \\
81^{* * *} \\
32 * * \\
48 * * * \\
26^{* *} \\
43^{* * *} \\
\text { N.T. } \\
\text { N.T. }\end{array}$ & $\begin{array}{c}3 \dagger \\
-34 \dagger \\
-7 \dagger \\
-3 \\
4 \\
-2 \\
-5 \dagger \\
9 \dagger \\
-26 \\
29 * * \\
5 \dagger \\
16^{*} \\
11 \\
3 \dagger \\
0 \\
-40 \\
-16\end{array}$ & $\begin{array}{l}\text { N.T. } \\
36^{* * *} \\
\text { N.T. } \\
66^{* * *} \\
\text { N.T. } \\
77^{* * *} \\
\text { N.T. } \\
15 . \\
95^{* * *} \\
\text { N.T. } \\
\text { N.T. } \\
\text { IN.T. } \\
\text { N.T. } \\
14^{*} \\
61^{* * *} \\
70^{* * *}\end{array}$ \\
\hline
\end{tabular}

$* \mathrm{P}<0.05$.

*** $\mathrm{P}<0.005$.

$\dagger$ Tested two hours after operation.

N.T. - Not tested.

cytotoxic reaction when taken during the first day after operation. In two patients (cases 19 and 21) the cytotoxic index though reduced was significant. One of these patients (case 21) had shown non-specific cytotoxicity against lung carcinoma cells before operation. In all eight cases in which the reduction of cell survival was assessed two hours after operation cytotoxicity 
was indetectable. The leucocyte count did not significantly differ during this period (mean $( \pm$ S.E.) before operation $6,900 \pm 850$, after operation $6,300 \pm 700$ ). In contrast to this lack of reactivity in the immediate postoperative period the leucocytes of seven out of eight patients who were retested were significantly cytotoxic one week after operation and in four cases the cytotoxic index exceeded preoperative levels.

Examples of the type of result obtained in studies on four patients are presented in table IV. Thus the patient in case 18

TABLE IV-Representative Experiments showing Variation of Cytotoxic Index in Postoperative Period

\begin{tabular}{|c|c|c|c|c|c|}
\hline & & \multicolumn{2}{|c|}{$\begin{array}{l}\text { Mean No. }( \pm \text { S.E. }) \\
\text { Cells surviving } \\
\text { Treatment with } \\
\text { Leucocytes from: }\end{array}$} & \multirow{2}{*}{$\begin{array}{c}\text { Cytotoxic } \\
\text { Index }\end{array}$} & \multirow[t]{2}{*}{$\mathrm{P}<$} \\
\hline & & Controls & Patient & & \\
\hline $\begin{array}{l}\text { Case } 2 \\
\text { Case } 11 \\
\text { Case } 12\end{array}$ & $\left\{\begin{array}{l}1 \mathrm{~d} \text { before operation } \\
\text { After induction } \\
1 \mathrm{~h} \text { after operation } \\
2 \mathrm{~h} \text { after operation } \\
1 \mathrm{~h} \text { before operation } \\
1 \mathrm{~d} \text { after operation } \\
8 \mathrm{~d} \text { after operation } \\
1 \mathrm{~d} \text { before operation } \\
8 \mathrm{~h} \text { after operation } \\
1 \mathrm{~d} \text { before operation } \\
\text { After induction } \\
2 \mathrm{~h} \text { after operation } \\
7 \mathrm{~d} \text { after operation }\end{array}\right.$ & $\begin{array}{r}136 \pm 8 \\
134 \pm 8 \\
134 \pm 8 \\
134 \pm 8 \\
74 \pm 4 \\
105 \pm 5 \\
64 \pm 5 \\
74 \pm 4 \\
105 \pm 5 \\
36 \pm 2 \\
21 \pm 2 \\
21 \pm 2 \\
118 \pm 4\end{array}$ & $\begin{array}{r}84 \pm 4 \\
84 \pm 6 \\
102 \pm 8 \\
130 \pm 8 \\
57 \pm 3 \\
108 \pm 4 \\
22 \pm 2 \\
55 \pm 3 \\
101 \pm 2 \\
20 \pm 2 \\
11 \pm 1 \\
26 \pm 2 \\
5 \pm 2\end{array}$ & $\begin{array}{r}37 \\
37 \\
24 \\
3 \\
24 \\
-3 \\
66 \\
26 \\
4 \\
46 \\
46 \\
-26 \\
95\end{array}$ & $\begin{array}{l}0.0005 \\
0.0005 \\
0.001 \\
0.04 \\
0.0005 \\
0.0005 \\
0.0005 \\
0.25 \\
0.0005 \\
0.0005 \\
0.0005\end{array}$ \\
\hline
\end{tabular}

had a cytotoxic index of 43 the day before operation. This was not significantly changed when leucocytes were taken immediately after induction, but two hours after surgery reactivity was indetectable. Leucocytes from this patient were again cytotoxic seven days after operation.

\section{Discussion}

Our results show that peripheral blood leucocytes taken before operation from patients with breast neoplasia are cytotoxic for cells cultured from breast carcinoma cells. This is in agreement with earlier studies (Hellström et al., 1971; Fossati et al., 1972; Baldwin et al., 1973) on human tumour-directed leucocyte responses. In contrast to their high reactivity against mammary carcinoma-derived cells leucocytes from patients were reactive against control cell lines in only two out of 17 tests. These results seem to indicate a relatively specific tumourdirected response in the cancer patient compared with normal patients. It must be emphasized, however, that no information is available to indicate that the cells cultured from the carcinoma are indeed tumour cells rather than stromal elements, and since all tests were performed in allogeneic combination the involvement of factors other than specific tumour antigens in the reduction of cell survival of target cells cannot be excluded (Takasugi et al., 1973).

In spite of these limitations in the test system our results do indicate that after surgical procedures performed under general anaesthesia there is a marked diminution of leucocyte activity as evidenced by a fall in the cytotoxic index compared with the preoperative level. This fall was apparent two hours after surgery in all the patients tested at this time. Reactivity was again detectable in preparations of patients' leucocytes one week after operation.

The transient fall of leucocyte responsiveness to non-specific mitogens (Riddle and Berenbaum, 1967; Park et al., 1971) and the inhibition of specific lymphocyte reactivity to tumour antigen (Cochran et al., 1972) and tuberculin (Berenbaum et al., 1973) immediately after surgery have been previously reported. The mechanism by which these effects occur has not yet been resolved.

It has been established that anaesthetics exert a reversible inhibitory effect on lymphocyte mobility (Nunn et al., 1970) and leucocyte function (Bruce, 1966). Though direct evidence that anaesthetic agents per se or their metabolites may influence specific cell-mediated immune reactions is not available this aspect requires closer assessment. Depression of immunological competence may also result from the increase in plasma cortisol concentration occurring within two hours of surgery (Sandberg et al., 1954). Corticosteroids are known to have a powerful suppressive effect on the immune apparatus (North, 1971) though Berenbaum et al., (1973) were unable to obtain convincing evidence of the involvement of cortisol in the postsurgical diminution of phytohaemagglutinin responsiveness.

This possibly multifactorial situation clearly requires further study and clarification since the inhibition of immunological competence may be relevant to postoperative infection (Goodman et al., 1968) and establishment of metastases (Krant et al., 1968). Our results indicate that leucocytotoxicity testing may be used as a monitor of specific immunological function in cancer patients and thus provides an appropriate model for further investigations on the mechanism of postsurgical immune depression under general anaesthesia in human patients. In addition, with the availability of an animal tumour model it should be possible to isolate the effects of anaesthesia and surgical trauma.

This study was supported by grants from the Medical Research Council and the Cancer Research Campaign. We thank Dr. M. Moore and Professor J. Parkhouse for their encouragement and Ian Kimber, Ann Lewis, and Roger Ferguson for skilled technical help.

\section{References}

Baldwin, R. W., et al. (1973). International fournal of Cancer, 12, 73. Berenbaum, M. C., Fluck, P. A., and Hurst, N. P. (1973). British fournal of Experimental Pathology, 54, 597

Böyum, A. (1968). Scandinavian fournal of Clinical Laboratory Investigation, 21, Suppl. no. 97, p. 31

Bruce, D. L. (1966). Fournal of Cell Physiology, 68, 81.

Cochran, A. J., et al. (1972). British Medical fournal, 4, 67.

Fossati, G., et al. (1972). International fournal of Cancer, 10, 391

Goodman, J., et al. (1968), New England fournal of Medicine, 278, 117.

Hellström, I., et al. (1971). International fournal of Cancer, 7, 1.

Krant, M. J., et al. (1968). Cancer, 21, 623.

North, R. J. (1971). Fournal of Experimental Medicine, 134, 1485.

Nunn, J. F., Sharp, J. A., and Kimball, K. L. (1970). Nature, 226, 85.

Park, S. K., et al. (1971). Lancet, 1, 53 .

Riddle, P. R., and Berenbaum, M. C. (1967), Lancet, 1, 746.

Riddle, P. R., and Berenbaum, M. C. (1967), Lancet, 1, 746.

Takasugi, M., and Klein, E. (1970). Transplantation, 9, 219.

Takasugi, M., Mickey, M. R., and Terasaki, P. I. (1973). Cancer Research 33, 2898. 